\title{
Analysis of the Countermeasures for Training Talents of Advanced Mathematics Teaching in Application-oriented Undergraduate Colleges
}

\author{
Weiming Cai
}

Hainan Tropical Ocean University, Sanya 572022, Hainan, China. E-mail: caiweiming9530@163.com

Abstract: With the transformation and development of local undergraduate colleges and universities in China, there are many problems in the training mode and teaching content of Advanced Mathematics professionals, which can no longer meet the demand for talents in the new era. In regard to the Advanced Mathematics Teaching major of application-oriented undergraduate colleges and universities, it should actively change teaching concepts and innovate teaching methods, so as to continuously improve the quality and level of teaching, and cultivate high-quality talents that meet the needs of social development. This article focuses on the cultivation of Advanced Mathematics Teaching professionals in application-oriented undergraduate colleges.

Keywords: Application-oriented Undergraduate Colleges; Advanced Mathematics Teaching Major; Talent Training; Countermeasure Analysis

Traditional undergraduate institutions focus on cultivating academic talents. However, with economic development and social progress, the cultivation of high-quality application-oriented and compound talents need more and more support. Undergraduate institutions must change their talent training model and innovate teaching methods, focus on cultivating talents' professional skills, innovation consciousness and ability, in order to improve talents' adaptability and job competence, so as to help them stand out in the fierce market competition. Next, take the Advanced Mathematics Teaching major as an example to talk about some thoughts on the countermeasures for talent training in application-oriented undergraduate colleges.

\section{Mathematics literacy that application-oriented talents should possess}

application-oriented talents, to be more specific, means that students have a strong ability to apply what they have learned and can skillfully use what they have learned to solve practical problems. Application-oriented talents are mainly engaged in technological production, and they need to apply what they have learned in the process of work. They need to combine theoretical knowledge, professional skills and actual production, and carry out technological innovation and reform in accordance with the actual situation of the post. At present, academic talents focus on improving theoretical research capabilities, while application-oriented talents focus on their practical operation capabilities. Professor Tieshu Xiao (Tsinghua University) once said: "One of the qualities of talents is to have a good mathematical language training. Because mathematics has a scientific language, it has the advantages of accuracy and simplicity to describe the phenomena and laws of things in mathematical language. It can be seen that all creations, inventions, engineering technology, etc. in society need to be expressed through mathematical language. The second quality is to master the thinking method of mathematics. Mathematics is the science of thinking, and the analogy induction, abstract generalization, and deductive argumentation, etc. in mathematics, which are necessary scientific thinking methods to promote the development of human creativity."

Copyright $(2020$ Weiming Cai

doi: 10.18686/ahe.v4i10.2877

This is an open-access article distributed under the terms of the Creative Commons Attribution Non-Commercial License (http://creativecommons. org/licenses/by-nc/4.0/), which permits unrestricted non-commercial use, distribution, and reproduction in any medium, provided the original work is properly cited. 
It can be seen that the advanced mathematics professionals of application-oriented undergraduate colleges must not only have high mathematical language ability and mathematical thinking ability, but also have the awareness and ability to closely link objective things with mathematics, and be able to pass mathematical thinking. They need to successfully convert real-life problems into mathematical models for effective solutions, and truly play the role of mathematics in real life.

\section{The importance of the reform of the training model for Advanced Mathematics teaching professionals}

With the advancement of science and technology, the role of mathematics in people's production and life continues to increase. It is no longer a simple tool or a language, but plays an irreplaceable role in all walks of life and all disciplines. The advantages of advanced mathematics education are prominent. Advanced Mathematics, which is the foundation and prerequisite of university education for students, especially for science and engineering students. Advanced Mathematics is an important guarantee for their mathematics and professional ability. However, with the changes in the university enrollment system and the social employment system, there are also many problems in the teaching of Advanced Mathematics. For example, with the implementation of the expansion policy, the gap between students in the same major is large. Another problem is the continuous reduction of the time space for mathematics major courses. Under the pressure of the "wide-caliber" of talent training, many undergraduate colleges and universities continue to compress the teaching hours of mathematics. On the contrary, the requirements for students' mathematics abilities are continuously improved. Besides, the compilation of Advanced Mathematics textbooks cannot keep pace with the times and cannot meet the needs of professional training goals. Also, most students lack the awareness and ability to use mathematical knowledge to deal with practical problems. Last but not least, there are many problems in the assessment methods, for instance, lack of diversity. Teachers still use the test scores under the traditional exam-oriented education system for assessment. These problems have largely restricted the improvement of the quality and level of training of advanced mathematics professionals.

\section{Countermeasures for cultivating Advanced Mathematics teaching professionals in application-oriented undergraduate colleges}

\subsection{Improve the cohesion of Advanced Mathematics professional curriculum teaching}

First, undergraduate colleges and universities should pay attention to the compilation of textbooks that are practical and effective. The current advanced mathematics textbooks of traditional undergraduate colleges are abstract, obscure, theoretical, and difficult to understand, which can easily dampen students' enthusiasm and confidence in learning. Under the new situation, before compiling or selecting teaching materials, colleges and universities should grasp the cognitive level of students, collect the opinions of mathematics teachers, professional course teachers, and student groups, and refer to high-quality higher teaching materials at home and abroad. Based on this, it is also needed to use higher education references that meets the actual situation because quality teaching materials can continuously improve the effectiveness of mathematics teaching.

Second, the teaching of Advanced Mathematics majors should adhere to the teaching principle of "Content is the foundation, supplemented by form", and always follow the teaching purpose of "learning for application". Specifically, when teaching, teachers should not pay too much attention to the logic and rigor of knowledge but focus on explain obscure and difficult mathematical knowledge to students intuitively and vividly, and on guiding students to master mathematical thinking methods and mathematics application ability. Professional teachers of Advanced Mathematics should pay attention to the connection between mathematics teaching and different majors. For example, when explaining mathematics knowledge, it can be expanded and fully integrated with examples of economic mathematics and architectural mathematics to guide students to understand different professional knowledge and lay a solid foundation for their future work in mathematics teaching.

\subsection{Attach great importance to infiltration of mathematical thinking and methods}

As we all know, the core of advanced mathematics lies in mathematical thinking and methods. The great mathematician Mr. Zhongsun Fu believes that the principle of "method as the longitude and knowledge as the latitude" should be adhered to when developing advanced mathematics teaching. The essence of application-oriented talents is to cultivate talents with a solid knowledge base, strong professional skills, and high mathematics literacy, especially mathematical thinking methods. Only 
when students realize the importance of mathematical thinking methods can they establish the consciousness of consciously using mathematical knowledge to face various problems, so that they will analyze and solve problems through mathematical thinking. This shows that it is very important to cultivate students' mathematical thinking methods.

It is not difficult to find that mathematics thinking methods are conceptual and implicit, permeating every mathematical knowledge point, and are invisible to the naked eye. Therefore, Advanced Mathematics teachers should pay attention to analyzing and revealing knowledge when carrying out mathematics teaching activities. The deep connotation of the point helps students to see the essence through the phenomenon, so as to successfully tap the deep value contained in the mathematical knowledge. At this stage, advanced mathematics methods include limited thought, function thought, classification thought, and the combination of number and shape. The various thoughts contain rich connotations and methodology. In the teaching process, teachers should combine different majors and use the professional background as an example to cultivate students' ability to use mathematical thinking methods in the process of analyzing examples, cultivate students' ability to analyze and solve problems, and improve students' creative thinking ability. For example, when explaining the knowledge points of the chapter Basic Formula of Calculus, because the calculus method is widely used in construction engineering, teachers can use the background of "calculating bridge pier earthwork" in the Engineering Cost major, so as to concretize and visualize the obscure knowledge, allowing students to feel the charm of mathematical thinking methods in actual cases, reduce the difficulty of learning, and training students' mathematical ability.

\subsection{Pay attention to the teaching of mathematical modeling}

It is very important to cultivate students' mathematical modeling ability in advanced mathematics teaching, and the mathematical modeling allows students to use mathematical knowledge and mathematical thinking methods in specific cases, use mathematical language and symbols, and transform specific mathematical problems into mathematical relations. The mathematical model is then used to calculate the model results through mathematical software and mathematical algorithms, and undergo testing. This is the specific process of mathematical modeling. The specific process of advanced mathematics modeling is as follows: First, carry out special lectures on mathematical modeling, in which to popularize the principles, methods and specific procedures of mathematical modeling to students, and train students to use Matlab software to generate their mathematical modeling awareness. Secondly, organize students to carry out mathematical modeling practice in different majors, and let students form mathematical modeling groups by themselves. This is mainly to apply the advanced mathematical knowledge and mathematical methods they have learned to solve practical problems in different majors. In addition, organize intra-school mathematical modeling competitions to test the effectiveness of student modeling in the competition mode, stimulate students' enthusiasm and initiative in mathematics learning and mathematical modeling, and select excellent groups from the intra-school competitions for systematic training and participate in provincial and even national college students' mathematical modeling competitions. This can cultivate students' long-term development ability, which in turn can continuously improve the quality and level of advanced mathematics teaching, and cultivate application-oriented and skilled advanced mathematics teaching professionals that meet the needs of social development.

\section{Conclusion}

In summary, the reform of the training model for advanced mathematics teaching professionals is a long and systematic project, which includes a wide range of fields. It requires the joint efforts of teachers and students to innovate teaching methods in an allround and multi-angle manner to improve teaching effectiveness, thereby training high-quality application-oriented talents.

\section{References}

1. Fu L. Discussion on Advanced Mathematics teaching reform in the training of application-oriented talents in local colleges. Education and Teaching Research 2012; 26(12): 91-92.

2. Duan X, Duan F, Li J. Exploration of Advanced Mathematics teaching reform based on the training of excellent talents. Contemporary Educational Theory and Practice 2013; 5(12): 94-95.

3. Xiong W. Countermeasures for Advanced Mathematics curriculum reform from the perspective of application-oriented talent training. Economic and Trade Practice, 2015; (15): 253. 